Research Paper

\title{
DOES THE IMPLEMENTATION OF SPECIAL ZONES OF SOCIAL INTEREST (ZEIS) ENCOURAGES ADEQUATE HOUSING IN PRECARIOUS SETTLEMENTS?
}

The Case of Sapé, São Paulo

Mariana REIS SANTOS; Brazil/The Netherlands

\begin{abstract}
With the establishment of the Constitution of 1988, a new approach to urban governance emerged in Brazil. The document brought significant changes regarding the right to the city and adequate housing, in particular, for the urban poor. The recognition of these rights triggered the experimentation with inclusionary policies around the country (Rolnik and Santoro, 2013). As a result, informal settlements started to be acknowledged as part of the formal city and were included in zoning and planning laws.
\end{abstract}

One of the main outcomes of these experiments was the creation of Special Zones of Social Interest (ZEIS), a land and housing policy that linked investments on infrastructure in precarious settlements to land regularisation processes. In 2001, ZEIS was incorporated into the City Statute, a document that established a range of collective rights to guide land use and development. Since then, the instrument has gained popularity in the country as a land regularisation tool. Nevertheless, a considerable share of settlements remains poorly built and addressing informality is still a challenge.

Therefore, this paper evaluated the co-relation between the implementation of ZEIS, land regularisation processes and provision of basic infrastructure in precarious settlements. More specifically, it measured the quality of State interventions supported by the zoning. By focusing on quality, this article aimed to evaluate whether ZEIS has encouraged adequate housing conditions for the urban poor or reinforced precarious patterns of development.

To explore this relationship, a case study was conducted on the performance of ZEIS in Favela of Sapé, a settlement in the West of São Paulo. As a methodology, case studies have become a common option for performing evaluations and analyse what a program, practice or police has achieved (Yin, 2012). Moreover, this research strategy commonly relies on various sources of field-based information (Yin, 2012). Accordingly, this paper comprised mainly primary qualitative data. It also made broad use of content and secondary analysis, with the goal of ensuring validity and reliability.

The performance of ZEIS in Sapé demonstrated that since its implementation, in 2001, tenure security and physical characteristics have enhanced considerably in the area, particularly, when it comes to housing quality and provision of basic 
infrastructure. Nevertheless, these accomplishments are being compromised by a strong process of reoccupation which is supported by illegal organisations. In addition, there is a delay of the Municipality in meeting the demands for housing in the area because of governance issues and mismanagement of financial resources.

This scenario, combined with a weak inspection body, has once again permitted the development of precarious housing and infrastructure in the area. It also has compromised the issuance of freehold land titles to the settlement's dwellers. In other words, the site is under a vicious circle where neither the provision of housing and infrastructure is enough to meet the demand nor the land regularisation is completed because of the reoccupations.

In sum, although the implementation of ZEIS seems to have a share of responsibility in Sapés upgrading process, the local authorities do not have the capacity of reinforcement necessary to maintain these improvements. Furthermore, it is fair to assume that the current legal framework provided by ZEIS is not adequate for the context of São Paulo and requires further adjustments. Not only because of the complex character of the city, but also because in practice, urban norms may be interpreted differently according to political and cultural conditions (Rolnik, 1997).

\section{Keywords}

Spatial Justice, Governance, Adequate Housing

\section{Introduction}

This article was based on the Master Thesis entitled "Does ZEIS encourages adequate housing in precarious settlements? The Case of Sapé, São Paulo", presented at the Institute for Housing and Urban Development Studies (IHS), in October 2018. As the mentioned thesis, this paper evaluates to what extend the implementation of Special Zones of Social Interest (ZEIS) facilitated the development of adequate housing in the Favela of Sapé, a settlement located in the West area of São Paulo. "Adequate" is hereby define as access to basic infrastructure, services and facilities, good location, legal security of tenure, affordability, accessibility, habitability and cultural adequacy.

To conduct this evaluation it was necessary to understand how ZEIS operates. Therefore, legislation, official documents, annual reports, policy documents, and GIS information were extensively analysed. Moreover, previous research was reviewed, with the goal of understanding the trajectory of the instrument and the challenges of design and implementation. In addition, to draw an overview of the current situation of the built environment of Sapé, semi-structured interviews were conducted with professors, government officials, and professionals engaged in the settlement's upgrading process.

The urban interventions in the settlement started in 2012 and are currently on its final stages. Nevertheless, the initial intervention plan suffered many alterations and several aspects were not implemented. In fact, there is no prediction of when or whether or not these aspects will be carried out (Formicki, 2017). Therefore, this article discusses the outcomes of the implementation of ZEIS in Sapé and the performance of the public authorities. Through this discussion, this paper evaluates the effectiveness of ZEIS as an 
upgrading tool and establishes whether the instrument has encouraged decent housing conditions or reinforced precarious patterns of development in the settlement.

\subsection{Informal development in Brazil}

Accommodate the abrupt population growth, caused by the current pace and scale of urbanisation, has been a major challenge for public administrations. On one hand, governance and public policies have a fundamental role on encouraging an equitable spatial development, particularly, when it comes to inclusionary measures and social assistance for vulnerable groups. On the other hand, overregulation and technocratic urban norms commonly difficult the access to the formal land market and, therefore, reinforce informality (Biderman and Smolka, 2009).

The issue of informal land development is acknowledged in Brazilian cities since the end of the XIX century. In fact, since then, informal settlements have been consolidated as the main alternative for low-income families to access the urban land market (Cardoso, 2007). This phenomenon was reinforced not only by historical inequalities and uneven distribution of land and wealth but also by the incapacity of the State of regulating the Real Estate Market. Not to mention the absence or ineffectiveness of housing policies for low-income families in the country.

As a consequence of this scenario, the development of the majority of Brazilian cities happened without planning and with the basic infrastructure following (instead of preceding) the occupation of the land (Cardoso, 2007). Because these occupations often happened in environmentally fragile areas, this pattern of development brought high financial and environmental costs for the public authorities. Furthermore, it shaped the access to basic infrastructure, services and facilities as a luxury, encouraging the speculation with land. In other words, the urban development in Brazil is marked by

"restricted conditions of access to land and housing; high costs of housing production and or urban services, aggravated even further by inflation and unequal (and unfair) patters of income distribution; real property treated as exchange value; extensive hoarding of idle land; and an intense speculation process" (Fernandes, 1993, pp. 213)

It is in this scenario of scarce public resources and high speculation with land that the favelas are formed.

\subsection{A shift on the approach to informal development}

The approach of the public administration to informal settlements was often inconsistent, varying from efforts of eradication to palliative improvements. Moreover, because there was no legal arrangement to support investments on infrastructure and services these areas, the public interventions were often ineffective. This started to change in the 1980s, with the new Constitution and subsequent implementation of the City Statute ${ }^{1}$. The City Statute brought significant changes to the approach to urban governance in Brazil; particularly, regarding the management of precarious settlements. Through the articulation of several

\footnotetext{
${ }^{1}$ The Federal law no. 10.257 of 2001, commonly called the City Statute, was created to regulate the Articles 182 and 183 of the Federal Constitution of Brazil which coordinates urban development policies.
} 
urban instruments, the document created the legal arrangement necessary to regulate and integrate these areas to the formal city.

One of the major instruments instituted were the Special Zones of Social Interest (ZEIS). In the process of building a new urban order based on the principle of the social function of property, ZEIS were consolidated as a unique type of zoning. The main objective of the instrument was to guarantee to low income families the access to urban land served with basic infrastructure, services and facilities. Therefore, ZEIS represented a shift on the approach to informal settlements. Because of the instrument, these areas were for the first time recognised as part of the formal city and included in planning and zoning laws.

\section{The case of Sapé}

Sapé is a precarious settlement located in the West of São Paulo, under the administration of the Butantã Borough, in the Rio Pequeno District (see Figure 1). The Butantã Borough is one of the wealthiest regions of the city and has significant points of interest such as the Hospital Israelita Albert Einstein, one of the most important private hospitals of the city, the Palácio dos Bandeirantes, seat of the São Paulo state government and the University of São Paulo (USP), one of the biggest universities of the country.

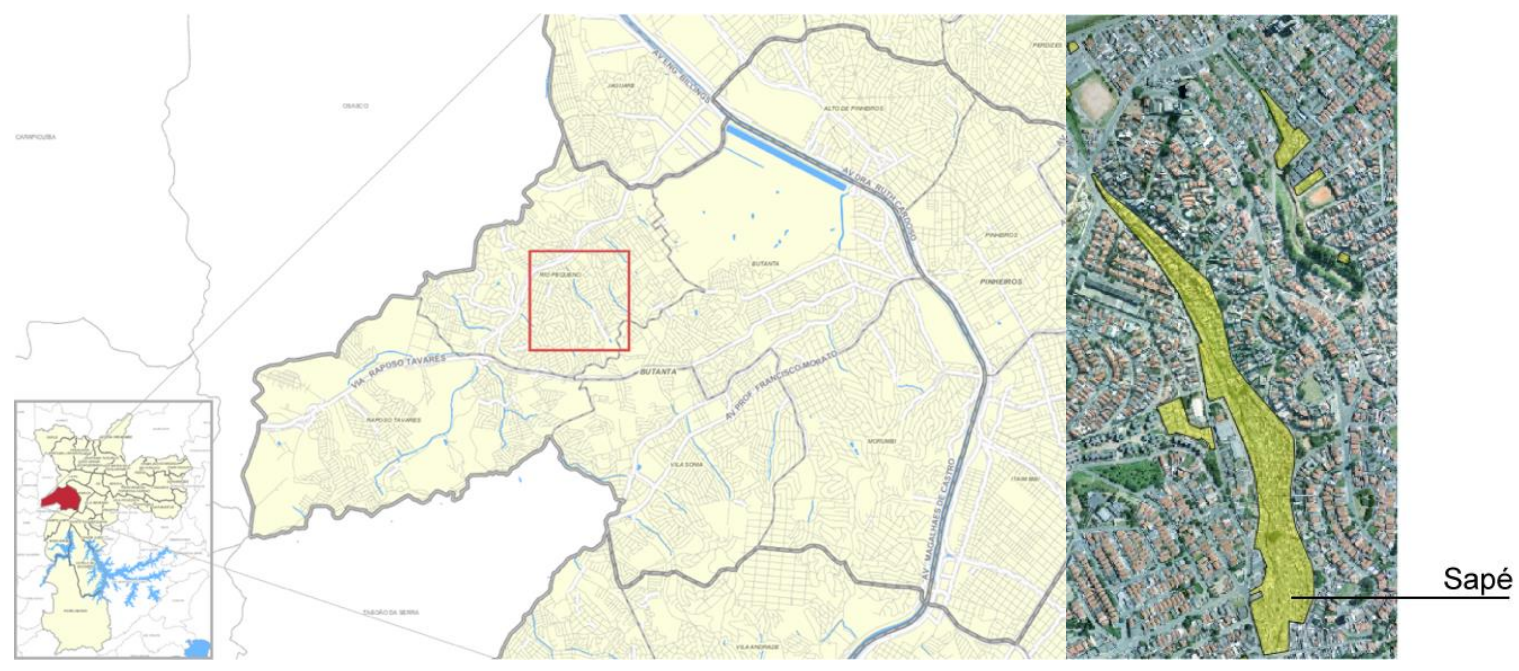

Figure 1 Location of Sapé in São Paulo

Rio Pequeno was mainly formed by pottery, quarry and construction workers, hired to build the university during the 1960's and 1970's, a moment of strong urbanisation in the city. Constructed in public land, the settlement, which started with a few houses along the Stream of Sapé, became a dense and precariously built slum. Because of this densification, the occupation overcame the stream, which led to precarious housing and sanitation conditions (Brandão and Leitão, 2016). Moreover, because of the proximity to the stream, the area went through several episodes of floods over the years, which regularly resulted in great material and human losses. 
The public interventions in Sapé occurred in a fragmented way and because of the environmental fragility of the area, the actions towards the depollution of the stream and relocation of dwellers situated in flood-prone areas were fundamental. Therefore, the actions of the public authorities in the area were marked by the tension between environmental demands and housing and urban infrastructure demands.

In 2002, Sapé was regulated as ZEIS by the PDE and incorporated into the Land Regularization Program, resulting in the provision of land titles even before any urban infrastructure arrangement (Grosbaum, 2010). In parallel, the Sapé Stream went through multiple interventions conducted by the Córrego Limpo and 100 Parques Programmes, which were concluded in 2009. The implementation of ZEIS brought about the urbanisation plan of the area. Nevertheless, because of the delay of the public authorities in articulating the necessary arrangements to initiate the construction works, the population in the area had increased and the urbanisation plan had to be readjusted. Finally, in 2010, a public bidding was made and the construction works, which are still running, began.

\section{The outcomes of ZEIS}

\subsection{The effectiveness of ZEIS as an instrument}

The demarcation of Sapé as ZEIS ensured the population of the settlement the right to usufruct from the city, in a good location. Therefore, the zoning overcame the "highest and best use" of land, by establishing areas of social interest in prime locations (Borelli and Santoro, 2015). Moreover, the institutional and legal arrangements required to implement the zoning permitted an active and democratic engagement of the community in the urbanisation process.

The intervention plan of Sapé has achieved significant improvements regarding the availability of basic services such as electricity, water, sewage and refusal disposal and, social services and facilities. The removal of dwellings from hazardous areas enabled significant improvements on the quality of the water of the stream. Additionally, it made room for the construction of public spaces, causeways, roads and, cycle paths. Another significant contribution to enlarge the availability of space was the verticalisation of the new housing units. This allowed the allocation of a higher number of people in a smaller area, what is beneficial if you consider the environmental gain to the region and the elevated number of removals conducted along the stream. Nevertheless, the positive outcomes of the urbanisation plan in the area may be at risk because of the strong process of reoccupation of common spaces and hazardous areas.

It is important to highlight that the approach of the Municipality was either to provide infrastructure and do not interfere in the dwelling's physical characteristics or provide infrastructure and reconstruct the dwellings completely. This indicates an unequal distribution of public resources in the area and favours part of the population instead of benefiting the population as a whole, in an equal manner. The performance of the Municipality demonstrates that the actions of the State often encourage injustice by promoting "private appropriation and accumulation of the commons, the resources, and the collective-created world" (Zárate, 2015, pp.27).

Another approach that disfavoured part of the population was the criteria to select the families that were entitled to these apartments. Because the intervention was made through 
a public-private partnership, the financial resources were held by the private sector. Therefore, among their criteria of selection, there was the ability of the family to pay for the new apartments. This is controversial because, through the selection of families with higher financial capability, the opportunity of accessing adequate housing is taken away from the dwellers that need it the most. This illustrates the positioning of Harvey (2015) that profit is commonly prioritised over people's rights, necessities, and well-being. Additionally, this criterion goes against the principle of ZEIS itself, which is to ensure the right to the city and housing to low-income groups.

Nonetheless, in a conflicted manner, the implementation of ZEIS has succeeded in providing legal security of the tenure to the inhabitants of Sapé. The zoning guaranteed to Sapé's dwellers the right to be relocated to the adjacent neighbourhoods and receive financial aid from the government to cover rental expenses. Moreover, the zoning also entitled the inhabitant out of the hazardous areas to remain on-site and, therefore, granted these dwellers the right to the city and subsequent accomplishment of the social function of property, cited by Borelli and Santoro (2015) as one of the positive outcomes of the zoning.

Nonetheless, the issuance of titles did not occur in the area yet because of the reoccupations supported by criminal organisations in the settlement. This demonstrates that perceived tenure security is not only provided to informal dwellers by public investments, as defended by Durand-Lasserve et all (2009), but also by the compliance with the demands of criminal organisations, that often overcome the power of the State in these areas. This confirms the affirmation that cities have become an expression of inequalities and violence (Zárate, 2015).

In Sum, the implementation of ZEIS in Sapé has formed a vicious circle where neither the provision of social housing and infrastructure is enough to attend the demand nor the land regularisation is completed due to the reoccupations that have been contributing to the increase on the population in the settlement. This vicious circle is illustrated below.

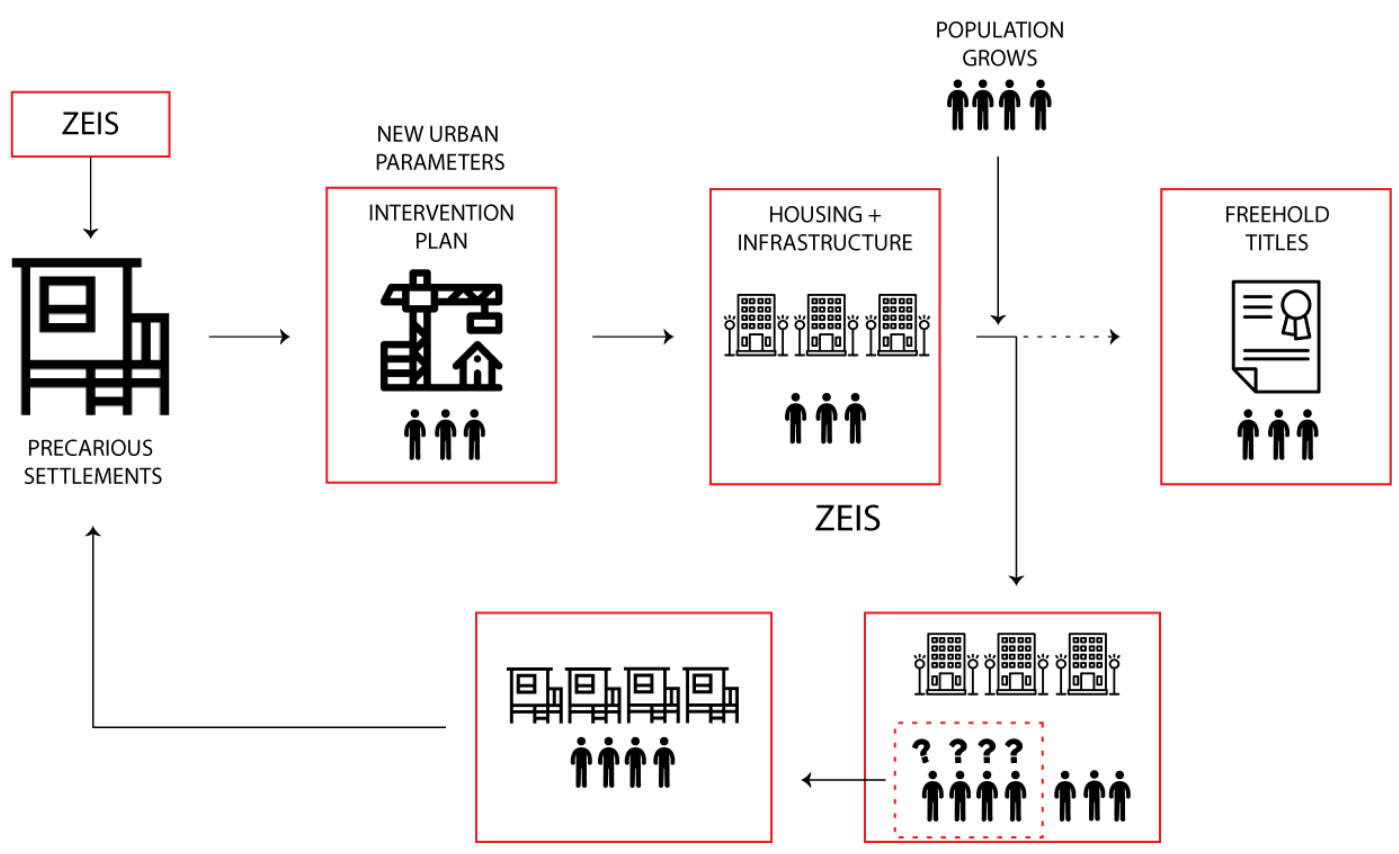


Figure 2 Vicious circle, an outcome of ZEIS in Sapé

\subsection{The impact of ZEIS on housing conditions}

Housing conditions have changed significantly in Sapé since the institution of ZEIS, particularly since 2011 when the most radical phase of the intervention started to be implemented. Before the zoning, a considerable share of the residential development in the settlement was in hazardous areas, subject to floods and landslides, which was a threat to the life of the dwellers living in these conditions. In addition, the inhabitants that were not in hazardous areas were provided with basic infrastructure and sanitation facilities, which by itself is already a significant advancement considering the precariousness of the settlement before the Public authority intervene. In addition, the area was provided with public spaces, sports facilities, cycle paths, and adequate roads. The construction of these soft services assisted the creation of a socially just space.

The relocation of people from hazardous areas was not only beneficial from a safety and health point of view, considering that most of these dwellers were poorly built and nearby the stream that was an open-air sewage, but also from an environmental perspective. These relocations allowed the depollution of the stream and the provision of sanitation systems to the area, as well as the mitigation of floods. In addition, the inhabitants that were living in precarious conditions around the stream were relocated to newly built apartments, constructed with durable materials an out of hazardous areas. However, a considerable share of dwellers that were relocated did not return to Sapé yet due to the lack of social housing, demonstrating that the demand for housing in the area is still higher than the supply. Furthermore, the actions of criminal organisations in the area have been encouraging the reoccupation of public spaces. This reoccupation process may trigger the precarious development of land in the area once again, considering that the supply of housing is, as mentioned, already insufficient.

\subsection{ZEIS and Adequate Housing}

When considering the dimensions of adequate housing posed by this paper, the most significant contribution of ZEIS was the provision of legal security of tenure. Although the issuance of titles has not occurred yet, alternative forms of tenure have been granted to the inhabitants of the settlement. Further, legal security of tenure has been ensured also to the inhabitants that were temporarily relocated to the neighbourhoods around Sapé. Nonetheless, the delay of the Municipality on concluding the construction works has been precluding the return of these families to the settlement, which constitutes a violation of their rights. Moreover, the elevated rental costs of the surroundings compromise another dimension of adequate housing that is affordability. This contributes to the criticism of Harvey (2012) and Lefebvre (1996) regarding the neoliberal approach that our cities are managed.

The financial burden of the urbanisation plan is also extended to the families that have remained on-site during the construction works. Although ZEIS is supposed to encourage housing affordability, the provision of public infrastructure and services to Sapé have had the opposite effect in the informal property transactions in the area. This is a common outcome of slum upgrading. Nonetheless, the zoning succeeds in containing the pressures of 
the formal Real Estate Market and, indeed, ensures the right to the city to slum dwellers (Borelli and Santoro, 2015). However, in Sapé, it has failed in meeting the demands of the lower income population for housing. This failure resulted mainly from the mechanisms used by the Municipality to finance these interventions, as well as the lack of a unified system to prioritize the demand for housing in the city. Furthermore, the engagement of the private sector in the urbanisation process of Sape and the incapacity of the local authorities of overcoming the interests of the latest resulted on the selection of families that had a better financial condition over families in hazardous areas. This situation compromises the accessibility of housing in the area. Nonetheless, this scenario is not triggered by the zoning, but for financial and public administration issues.

Regarding the cultural adequacy of the environment constructed in the area, ideally, the new housing should follow features similar to the existing dwellings, what does not occur. By choosing to verticalise the new units, the Municipality contradicts the character of the area. On the other hand, in a megacity like São Paulo where the land is scarce, particularly to produce social housing, this may be a suitable approach. Furthermore, it has ensured to most of the population the right to remain on-site and enjoy a physically safe location, what according to Caldas (2009) is the most adequate approach to intervene in informal areas.

The verticalisation of the housing also promoted significant environmental improvements. A considerable share of these enhancements is a result of the depollution of the Sape stream and the construction of adequate sanitation systems, which was only possible because of the removal of dwellers from the stream floodplain due to the verticalisation approach. Accordingly, it has also contributed significantly to the habitability of the settlement. Nevertheless, the efforts to clean the stream were a result of the combined actions of the Córrego Limpo and 100 Parques programmes and not of the implementation of the zoning,

Additionally, to ensure such habitability, a high number of removals had to be conducted in the settlement, which violates the right of these dwellers of remain on-site. At the same time, it was necessary because of the precarious and dangerous conditions on which these inhabitants were living. Although these removals are temporary, it may have a negative impact on the livelihood and social connections of Sapé's inhabitants, even with the concern of the Municipality in relocating these dwellers to adjacent neighbourhoods. However, the socioeconomic impact of urban interventions instigated by the implementation of ZEIS, as well as the impact of relocation on the livelihood of dwellers subject to these interventions shall become the object of further research.

Summarizing, the implementation of ZEIS in precarious settlements seems to have a share of responsibility on the adequacy of housing produced in these areas. Particularly, when it comes to ensuring a good location in the city and providing the legal security of tenure necessary to remain in such good location, which guarantees to the inhabitants of these settlements the right to usufruct from serviced land. Nevertheless, the urban parameters permitted by the zoning seems to be distorted to fulfil the private sector requirements, as can be perceived by how the affordability and accessibility of housing were managed in Sapé. In addition, the major advancements on habitability result from the depollution of the stream, which is an outcome of a public-private initiative that is not connected to the zoning, revealing that the implementation of ZEIS was not significant to this process. At the same time, the special urban parameters established by ZEIS permitted a higher use of land, which made room for the construction of public spaces and infrastructure. These were major 
improvements to the settlement. And finally, as already mentioned, although verticalisation is not culturally adequate to the profile of Sapé, it enabled important advancements to the area. Accordingly, the overall contribution of the implementation of ZEIS in precarious settlements to the encouragement of adequate housing is summarized in the following scheme.

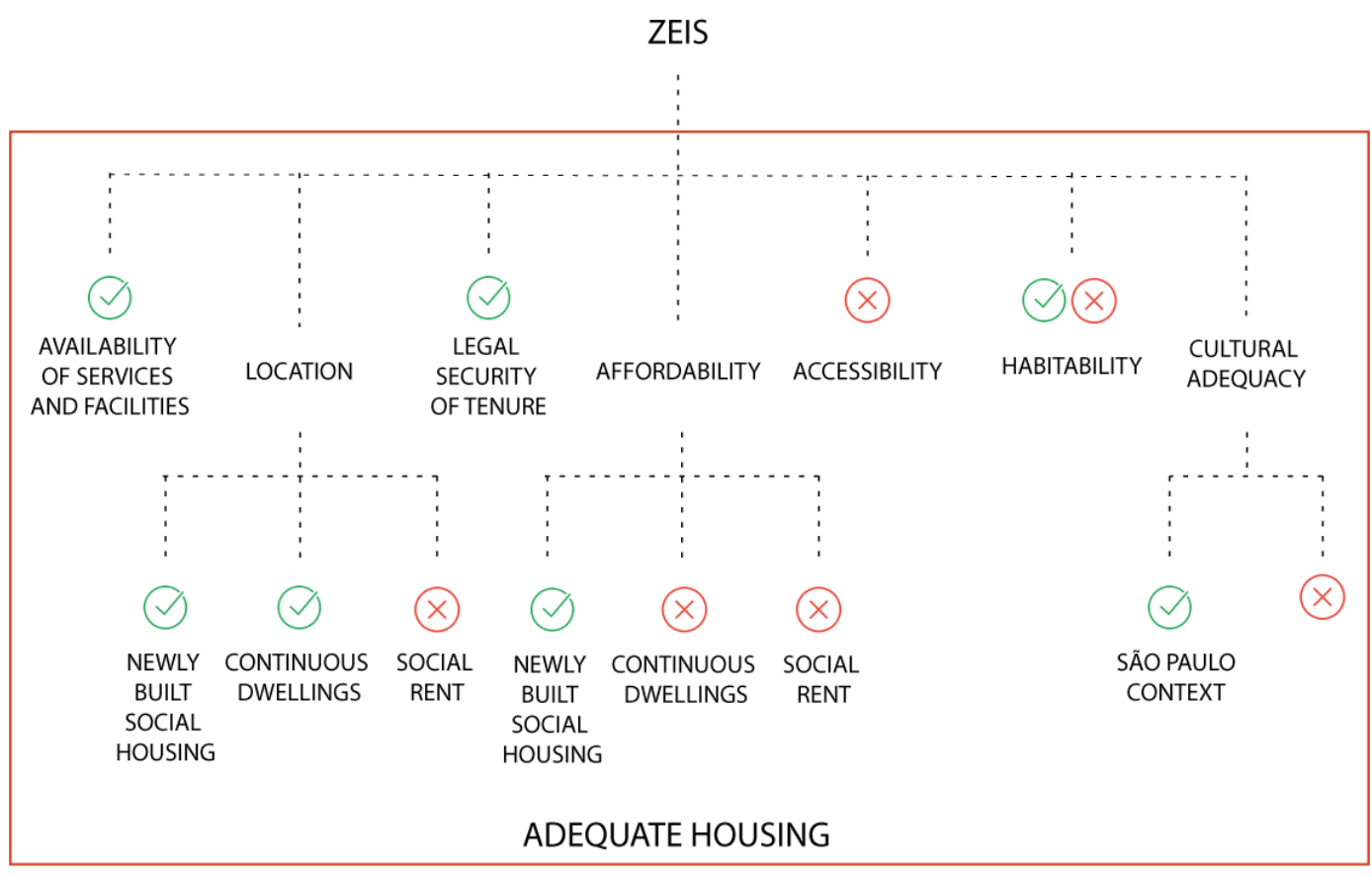

Figure 3 How ZEIS influenced adequate housing in the case of Sapé

\section{Conclusion}

A considerable share of the negative outcomes of the implementation of ZEIS is related to the lack of financial resources and governance issues. This is illustrated by the case of Sapé, which despite being a ZEIS since 2001, did not suffer significant interventions until 2011, when the financial resources of the central government were made available by the Growth Acceleration Programme (PAC). Besides that, there is a clear delay on the actions of the Land Regularisation Sector (CRF) in reinforcing the interventions made by the Physical-Territorial Sector - CFT (the sector responsible for the coordination and execution of projects). In addition, precarious settlements also face issues caused by changes on administration. For instance, the issuance of CDRU's to Sapé's dwellers even before the implementation of ZEIS and, thereafter, removal of the families that received the concession. Moreover, the instrument seems to be often distorted to attend the demand of the Real Estate Market for profit. In addition, although ZEIS receives financial resources from other urban policies, it seems that in the context of São Paulo, the production of housing has been prioritized over improvements in precarious settlements, again, to satisfy the demand for profit of the private sector. 


\section{References}

Biderman, Ciro; Smolka, Martim (2009). "Measuring Informality in Housing Settlements: Why bother?"

Borelli, Julia; Santoro, Paula (2015). “Os desafios de se produzir Habitação de Interesse Social em São Paulo: da reserva de terra no zoneamento às contrapartidas obtidas a partir do desenvolvimento imobiliário ou das ZEIS à cota de solidariedade".

Brandão, A; Leitão, Karina (2016). “Os Programas de Urbanização de Favelas em São Paulo: As Transformações Físico-urbanísticas da Favela do Sapé".

Caldas, Nisimar (2009) “Os Novos Instrumentos da Política Urbana: Alcances e limitações das ZEIS”, PHD, São Paulo: Universidade de São Paulo

Cardoso, Adauto (2007) "Avanços e desafios na experiência brasileira de urbanização de favelas".

Fernandes, Edesio (1993), The Regularisation of Favelas in Brazil - The case of Belo Horizonte. 2 (SAGE), pp. 211-236.

Formicki, Guilherme (2017), "As Falhas do poder público na condução da política de urbanização de favelas no município de São Paulo".

Grosbaum, Marcia (2012), "O espaço público no processo de urbanização de favelas".

Harvey, David (2012) Rebel Cities - From the right to the city to the urban revolution. London: Verso.

Intervenções Contemporâneas em Cidades da América do Sul: Estudo das transformações territoriais em assentamentos precários. São Paulo/Brasil - Medellín/Colômbia. 2018. Available at: http://www.favelasaopaulomedellin.fau.usp.br/publicacoes/[ [Accessed 2018].

Lefebvre, Henri (1996) The Right to the City. 1996. Writing on Cities. Blackwell. pp. 147.

Rolnik, Raquel (1997), "São Paulo, um século de regularização urbanística: para quem, para quê?".

Rolnik, Raquel; Santoro, Paula. (2013) "Zonas Especiais de Interesse Social (ZEIS) em cidades brasileiras: Trajetória Recente de Implementação de um Instrumento de Política Fundiária"

Yin, Robert (2012) Case Study Research: Design and Methods, 5th edition, Thousand Oaks, United States: SAGE Publications Inc.

Zárate, L., 2015. Right to the City for All: A Manifesto for Social Justice in an Urban Century 